\title{
Is Earth recognized as a finite system in corporate responsibility reporting?
}

\author{
Bjørn, Anders; Bey, Niki; Georg, Susse; Røpke, Inge; Hauschild, Michael Zwicky
}

Published in:

Journal of Cleaner Production

Link to article, DOI:

10.1016/j.jclepro.2015.12.095

Publication date:

2017

Document Version

Peer reviewed version

Link back to DTU Orbit

Citation (APA):

Bjørn, A., Bey, N., Georg, S., Røpke, I., \& Hauschild, M. Z. (2017). Is Earth recognized as a finite system in corporate responsibility reporting? Journal of Cleaner Production, 163, 106-117.

https://doi.org/10.1016/j.jclepro.2015.12.095

\section{General rights}

Copyright and moral rights for the publications made accessible in the public portal are retained by the authors and/or other copyright owners and it is a condition of accessing publications that users recognise and abide by the legal requirements associated with these rights.

- Users may download and print one copy of any publication from the public portal for the purpose of private study or research.

- You may not further distribute the material or use it for any profit-making activity or commercial gain

- You may freely distribute the URL identifying the publication in the public portal

If you believe that this document breaches copyright please contact us providing details, and we will remove access to the work immediately and investigate your claim 


\title{
Is Earth recognized as a finite system in corporate responsibility reporting?
}

Authors: Anders Bjørn*1, Niki Bey ${ }^{1}$, Susse Georg ${ }^{2}$, Inge Røpke², Michael Zwicky Hauschild ${ }^{1}$

*corresponding author: anbjo@dtu.dk

${ }^{1}$ The Technical University of Denmark, Produktionstorvet, Building 424, 2800 Kgs. Lyngby, Denmark

${ }^{2}$ Aalborg University, Department of Development and Planning, A.C. Meyers Vænge 15, 2450 København

SV, Denmark

\begin{abstract}
Companies are increasingly encouraged to frame their sustainability activities and communication around ecological limits, as captured by concepts such as planetary boundaries, climate tipping points or local assimilative capacities. Ecological limits may serve as a scientific basis for defining environmental sustainability targets at the company level and, moreover, inspire companies to align their product portfolios with emerging societal needs related to sustainable transformations. Although corporate environmental reporting is widely researched, little is known about companies' use of the ecological limits concept in their communication.
\end{abstract}

This study presents a comprehensive review of references made to ecological limits in corporate responsibility $(C R)$ reports. An exhaustive list of terms related to ecological limits was developed and used to search the CorporateRegister database, which contained approximately 40.000 CR reports dating from 2000 to 2014. For every identified reference, we analyzed the context in which the ecological limit term was used in the CR report.

We found a 10-fold increase in the number of references made to ecological limits in CR reports during the period 2000 to 2014. The number of CR reports published in this time period has also increased at a similar rate. Hence, the proportion of companies referring to ecological limits in their CR reports has over the years remained stable; roughly $5 \%$. The most commonly invoked ecological limits were related to climate change and references to " $2{ }^{\circ} \mathrm{C}$ " were by far the most frequent. The vast majority of companies referring to ecological limits did so without specific references to ongoing or planned changes in their activities as a consequence of recognizing these limits. Only a small percentage, predominately high-tech companies (31 in total), explicitly used ecological limits to define targets for resource consumption, emissions reductions and/or as a stated reason for adjusting their product portfolio. In defining targets for resource consumption or emissions, only a few CR reports dealt explicitly with the issue of allocating resource and emission rights within ecological limits amongst companies and other actors. A longitudinal study of three companies showed that these did not directly report progress towards planned changes based on ecological limits and offered explanations as to why some companies abandoned planned changes altogether.

Our findings provide novel insights into the current use of the ecological limits by companies and may be useful for actors trying to motivate companies to align their activities with the finite nature of Earth's natural systems. 
Bjørn A, Bey N, Georg S, Røpke I, Hauschild M Z (2016);

Is Earth recognized as a finite system in corporate responsibility reporting? Journal of Cleaner Production, Vol. xxx (2016), pp. 1-12, online 13 January 2016 http://dx.doi.org/10.1016/j.jclepro.2015.12.095

\section{Keywords}

Planetary boundaries; Sustainability criteria; Sustainable transformations; CorporateRegister;

Environmental Sustainability; Corporate environmental strategies 


\section{Introduction}

An increasing number of companies is reporting on the sustainability of their business and how they are contributing to sustainable development ${ }^{1}$, commonly defined as "...development that meets the needs of the present without compromising the ability of future generations to meet their own needs (WCED, 1987)." Sustainable development is, however, a contested term because of the subjective nature of needs and the complex task of identifying the conditions required for meeting them. For example, some promote economic growth (perhaps involving some environmental considerations) as a means to meet the needs of the world's poor, while others argue that the environmental degradation associated with economic growth will jeopardize the very meeting of human needs (Robinson, 2004). Further, the practice of sustainability reporting has been criticized as it can easily be misused by companies motivated by profit rather than a genuine interest in improving environmental and social conditions (Milne and Gray, 2012; Robinson, 2004).

Meanwhile, collective efforts to ensure sustainability are currently insufficient, because while meeting human needs today and in the future depends on well-functioning environments (Whiteman et al., 2013), environmental monitoring shows that the state of the environment is deteriorating globally (Steffen et al., 2015; WRI, 2005). Our dependency on the environment is captured in the common definition of environmental sustainability "...seek[ing] to improve human welfare by protecting the sources of raw materials used for human needs and ensuring that the sinks for human wastes are not exceeded, in order to prevent harm to humans" (Goodland, 1995). This definition resonates with the concept of ecological limits, which holds that resource use and pollution should be restricted to certain levels to protect ecosystem functions and services critical for meeting human needs (Costanza and Daly, 1992). ${ }^{2}$ Ecological limits have been quantified for various pollutants and resource use at different spatial scales, e.g. environmental flow requirements for freshwater use at the scale of a river basin (Hoff et al., 2014; Pastor et al., 2013), critical loads for the deposition of acidifying air emissions at the regional scale (Hettelingh et al., 2007), and planetary boundaries for gas emissions contributing to climate change and stratospheric ozone depletion at the global scale (Rockström et al., 2009; Steffen et al., 2015). Although ecological limits cannot be extended through technological means, technological innovations can increase the eco-efficiency of products and services, thus, allowing for larger quantities of these to be produced and consumed within ecological limits (Robinson, 2004). ${ }^{3,4}$

Recently, a number of initiatives from NGOs, nonprofit organizations, think tanks, research organizations, consultancies and industry organization have encouraged companies to adopt an ecological-limit-based understanding of what constitutes a sustainable company. McElroy \& van Engelen (2012), for instance, call for companies to perform "context-based" sustainability reporting, where context refers to carrying capacity (synonymous with ecological limit) of affected ecosystems. Context-based sustainability reporting

\footnotetext{
${ }^{1}$ See Robinson (2004) for similarities and differences in meaning and use of the two terms.

${ }^{2}$ See Moldan et al., (2012) for an elaboration on the relationship between indicators of environmental sustainability and ecological limits.

${ }^{3}$ Geoengineering, in principle, has the potential to manipulate ecological limits related to the climate system, but this concept faces many challenges of technological, environmental, economic, political and ethical nature (Caldeira et al., 2013), which makes it unlikely to play an important role in responses to climate change.

${ }^{4}$ The ecological footprint indicator may give the impression that technology can in fact extend ecological limits because the biocapacity parameter (i.e. the potential yield of productive land) can be increased (at least for some time) by, for example, the use of fertilizer and pesticides (Borucke et al., 2013; Giampietro and Saltelli, 2014). However, biocapacity is not synonymous with ecological limit because biocapacity is a characteristic of a manmade system (a cultivated area) and not of a natural system.
} 
is also encouraged in the latest G4 guideline of the Global Reporting Initiative. ${ }^{5}$ The World Business Council for Sustainable Development's (WBCSD) Vision 2050 and Action 2020 encourage companies to commit to the challenge of staying within ecological limits, based on the ecological footprint and planetary boundaries concepts (WBCSD, 2014, 2009). The One Planet Thinking model was developed to translate planetary boundaries to a business context (Ecofys, 2015). Other initiatives focus exclusively on climate-change and urge companies to reduce their greenhouse gas (GHG) emissions in line with global reduction needs so as to avoid exceeding climate tipping points (CDP, 2014; ClimateCounts, 2013; GreenBiz, 2014; Krabbe et al., 2015; Randers, 2012; WWF, 2013). In the light of these calls, Baue and McElroy (2013) encourage identification of the companies that use ecological limits to define corporate targets for resource use and pollution and analysis of the manner in which this is done. We argue that attention should also be given to the ecological limits concept's potential influence on changes in product portfolios, since staying within ecological limits will mean that some of today's products and services will become redundant in the future. Fossil fuels are obvious examples, while the need for new types of green-tech-related products and services will grow (SustainAbility, 1995). This means that the ecological limits concept can be expected to influence different types of companies' product portfolios in different ways.

In this study we examine how the ecological limits concept figures in stakeholder communication in the form of corporate responsibility (CR) reports. ${ }^{6}$ First, we estimate the share of companies referring to ecological limits in their reports based on a systematic text analysis of these reports. This is followed by a context analysis of the ecological limit references with the aim of exploring the extent to which companies present targets for resource use and pollution and/or adjustments of product portfolios aligned with these ecological limits references and how these reporting activities develop over time. In interpreting the outcomes of this analysis we focus on 1) trends in references to ecological limits by different types of companies, 2) environmental issues covered by the ecological limits referred to and 3) companies' allocation of overall sustainable levels of impacts as defined by the ecological limits. Given that large companies are the most likely to issue CR reports, SME's are underrepresented in this study. Also, companies that do not issue $C R$ reports in the English language have for practical reasons been omitted. Our target audience is 1) researchers wanting to understand corporate use of the ecological limits concept and 2) initiatives, such as those mentioned above, seeking to effectively encourage companies to adopt ecological limits in their management and reporting practices.

\section{Methods}

The review consisted of 1) a screening of all CR reports issued from 2000 to 2014 and included in the CorporateRegister database (CR, 2014a); 2) a context analysis of the reports of this database and 3) an indepth longitudinal study of a few selected companies' reports. We chose the CorporateRegister database because it is the largest regularly updated commercial database of its kind, estimated to cover at least $90 \%$

\footnotetext{
5 "This involves discussing the performance of the organization in the context of the limits and demands placed on environmental or social resources at the sector, local, regional, or global level. For example, this can mean that in addition to reporting on trends in eco-efficiency, an organization may also present its absolute pollution loading in relation to the capacity of the regional ecosystem to absorb the pollutant." (GRI, 2013). The Global Reporting Initiative has, however, been criticized for not providing concrete guidance on this matter (Baue, 2013; GRI, 2013).

${ }^{6}$ We use the term "corporate responsibility report" as is used by the CorporateRegister database (CR, 2014a), according to which a corporate responsibility (CR) report can be any type of non-financial report. The title of a CR report typically contains one of the following terms: corporate social responsibility (CSR), "sustainability", "environment"al and integrated." Note that we do not encourage interchangeable use of the terms, which cover different concepts (Milne and Gray, 2012).
} 
of all reporting companies going back almost two decades (CR, 2014b). As of November 2014 the database contained approximately 40.000 Anglophone reports covering 12.000 companies. Our systematic approach, essentially covering all CR reports written in English during the period, guaranteed a solid empirical basis for the analysis.

\subsection{Screening}

The screening was based on a list of search terms related to ecological limits. The list was developed through multiple iterations: First we applied terms used by $\operatorname{WBCSD}(2014,2009)$ and Bjørn \& Hauschild (2015) as search terms. This returned a number of references from the CorporateRegister database pdf search tool where each reference corresponds to a single incident of the use of the search term in a specific CR report. While conducting the context analysis of each reference (see below), additional terms related to ecological limits terms were identified as some reports used more than one term related to ecological limits. The new terms were applied in new searches and also combined to create additional new terms. For instance, all combinations of identified synonyms for "natural" (i.e. "ecological", "environmental", etc.) and for "limit" (i.e. "constraint", "threshold", "boundary", etc.) were used as search terms. The iterative procedure was repeated until no new search terms were identified in order to maximize the chance of having identified all CR reports referring to ecological limits. The procedure applied here is very similar to the technique known as (citation) pearl growing within the field of online library searching (Hartley et al., 1990; Schlosser et al., 2006). Other librarian techniques were found not to be suitable for identifying all CR reports referring to ecological limits because they rely on the use of Boolean operators (i.e. "and", "or" etc.), which are not supported by the CorporateRegister pdf search tool. In order to ensure that identified references had a high relevance to the ecological limit agenda and to keep the amount of data manageable, search terms related to the following topics were excluded: policy targets and regulatory thresholds, carbon neutrality, the Natural Step, Cradle to Cradle, circular economy, resilience and resource scarcity. The rationale for these exclusions is presented in S1. The resulting list of search terms consists of 286 terms presented in S2. For each search term the number of relevant references given by the pdf search tool was noted for each year since 2000. A reference was considered irrelevant when it was unrelated to ecological limits, for instance a thermostat being turned down "2 degrees" or a logistics company's transportation "carrying capacity" being reported. The screening was carried out during November 2014.

\subsection{Context analysis}

The contexts in which the search terms appeared in the reporting were analyzed by accessing each CR report containing one or more references to ecological limits in pdf format from the CorporateRegister database and reading the surrounding text paragraphs and any figures and tables to which the references related. Reporting companies were subsequently categorized according to whether they:

A. Referred to ecological limits without stating these as reasons for any ongoing or planned changes in activities.

B. Defined quantitative targets with deadlines for resource consumption and/or emissions based on ecological limits and:

1. Presented no strategy for how to meet targets, or

2. Presented a strategy for how to meet targets.

C. Stated ecological limits as reasons for adjusting their product portfolio and:

1. Presented ongoing adjustments, and/or

2. Presented planned future adjustments. 
This categorization allowed for distinguishing between companies merely demonstrating awareness of ecological limits (group A) from companies actively using ecological limits as reasons for changes in governance (group B) or business (group C) in their stakeholder communication. Note that a single company could belong both to the $B$ and $C$ group. Some $C R$ reports referred to other company documents or website content, but our analysis is, for practical reasons, based exclusively on the CR reports in the CorporateRegister database. Due to the scope of this journal we chose to focus the context analysis on companies producing physical products. Companies from the following sectors were, therefore, per default, categorized as ' $A$ ' group companies (despite that some of them may fit the criteria for $B$ and $C$ group companies): Banks, Equity Investment Instruments, Food \& Drug Retailers, General Financial, General Retailers, Life Insurance, Non-equity Investment Instruments, Nonlife Insurance and Support Services. Companies within these sectors accounted for $23 \%$ of the approximately 12.000 companies in the database. As elaborated in Section 4.4, we do not, by this delimitation, mean to say that references to ecological limits by service oriented companies are irrelevant.

In order to further characterize the 'population' of companies actively using ecological limits in their stakeholder communication, group B and C companies were classified according to 1 ) sector and country of origin, 2) environmental problem(s) covered by the ecological limit(s), and, only for B companies, 3) the part of their products' life cycles covered by their performance targets, i.e. the system boundary. The Bcompanies' quantitative targets may pertain to products or to aggregated production (the total volume of all products produced by a company). In both instances, the corresponding system boundaries for resource use and pollution accounting may encompass the entire life cycle (or value chain) or only parts of the life cycle, such as the use stage or the industrial processes owned by the company.

\subsection{Longitudinal study of three $B$ and $C$ companies}

To analyze how ecological limits have been used in stakeholder communication over time, we selected three $B$ and $C$ companies as cases. To ensure sufficient time series of data, we chose companies for which the criteria for the $\mathrm{B}$ or $\mathrm{C}$ group (stating ecological limits as reasons for changes in either governance or business) were applicable for a minimum of 5 consecutive years. The companies were furthermore selected to ensure diversity in terms of sector and country of origin, system boundary applied and environmental problems covered. We focused on the development in time of two factors: 1) the presentation of planned changes based on ecological limits and 2) reporting of progress towards meeting these planned changes. The longitudinal studies expanded on the context analysis in two ways: 1) the targets and strategies motivated by ecological limits were evaluated relative to the other content of the CR reports to identify changes in the case companies' emphasis of these targets and strategies. 2) Reports from before and after the companies fitted the criteria for the B or C group were scanned for clues as to why the active use of ecological limits began and why it ended (for case companies not fitting the criteria for the $\mathrm{B}$ or $\mathrm{C}$ group in the most recent reporting year(s)).

\section{Results}

\subsection{Screening}

Of the 286 search terms, 93 terms returned relevant references by the CorporateRegister database pdf search tool (CR, 2014a). ${ }^{7}$ Figure 1a shows the numbers of relevant references returned in the period $2000-$

\footnotetext{
${ }^{7}$ The remaining 193 search terms all originated from combinations of previously identified search terms and either returned no references or only irrelevant references, i.e. without connection to ecological limits.
} 
2014 (as of 24. November 2014) across all CR reports in the database. Figure $1 \mathrm{~b}$ shows the numbers of relevant references divided by the number of CR reports published each year.

\section{[Insert Figure 1 here]}

In Figures 1 the ecological limit terms were grouped according to the type of environmental problems they related to: "Overarching" refers to generic terms, e.g. "ecological limit" and "carrying capacity"; "planetary boundaries" refers to the concept of Rockström et al. (2009) and Steffen et al. (2015) that is concerned with the functioning of the Earth System and included terms such as "safe operating space" and "boundaries of the planet"; "Emission" refers to terms related to unspecified emission limits, such as "absorption capacity" and "critical load"; "Climate change" includes terms related to tipping points of the climate system, e.g. " $2{ }^{\circ} \mathrm{C}$ " and " $450 \mathrm{ppm}$ "; "Resource" covers terms related to resource limitations, e.g. "supply limit" and "resource constraint"; "Water" covers terms related to water availability such as "Environmental flow requirement" and "water constraint (see S3 for the grouping of each search term).

Overall, most references fell into the category "overarching", meaning that companies more frequently use generic terms for ecological limits than terms that relate to a specific environmental problem. Ecological limit terms related to "climate change" returned by far the most references of all emission related terms. Five terms returned more than 100 relevant references in 2000-2014; these were " $2^{\circ} \mathrm{C}$ ", "carrying capacity", "environmental constraint", "environmental limit" and "resource constraint." S3 shows the number of references returned for all 93 relevant search terms in the period 1995-2014.

According to Figure $1 \mathrm{a}$, the number of references to ecological limits increased by more than a factor 10 (from 21 to 233 references) from 2000 to 2013 (the small decrease in 2014 compared to 2013 can be explained by the fact that not all CR reports published in 2014 were included in the CorporateRegister database as of 24. November 2014). However, Figure $1 \mathrm{~b}$ shows that due to a parallel increase in the number of published CR reports, the number of references to ecological limits per 100 CR reports was found to remain relatively stable at 5 throughout the entire period. In translating this number to the share of companies that refer to the covered ecological limit terms two sources of bias needed to be considered: 1) Each report may refer to more than one ecological limits term (e.g. both " $2{ }^{\circ} \mathrm{C}$ " and " $450 \mathrm{ppm}$ "). Hence, some reports have been double counted in the 5 references per $100 \mathrm{CR}$ reports, which therefore represent less than 5 companies per 100 CR reports. 2) Some companies published more than one CR report each year (for instance, one dedicated to "CSR" and one to "sustainability", however companies distinguish between these terms). Accordingly, the annual pool of companies is smaller than the annual pool of CR reports, meaning that $100 \mathrm{CR}$ reports cover less than 100 companies. For the $B$ and $C$ companies (see below) the effects of these two sources of bias were found to approximately cancel out. We assume that $B$ and $C$ companies in this aspect are representative of all companies referring to ecological limits. We thus estimate the share of companies in the database referring to ecological limits to be around $5 \%$ in any year of the 2000-2014 period. So, a short answer to the question posed in the title of this paper is "not really".

When considering the development of each group of ecological limit terms in Figure 1, it can be seen that the number of references to climate change peaked in 2010 with a total of 87, coinciding with the publication of the Copenhagen Accord of December 2009, which recognized "the scientific view that the increase in global temperature should be below 2 degrees Celsius" (UNFCCC, 2009). References to planetary boundaries only began in 2011 following the 2009 publication of Rockström et al. (2009) and has since then increased, although the total number of references are still modest ( 27 as of 24 . November 2014). 


\subsection{Context analysis}

\subsubsection{Group A}

When examining the context of each relevant reference returned by the database, it was found that an overwhelming majority (approx. 96\%) of the reporting companies could be characterized as group $A$. These companies merely demonstrated awareness in that they referred to ecological limits without stating these as reasons for any ongoing or planned changes in activities. Typical examples of such awareness demonstration are when companies in the beginning of CR reports use an ecological limit term as part of a sustainability definition or to argue the need of sustainable development (ecological limit terms in bold): "Sustainability includes living within environmental limits and ensuring a just and healthy society." (UG, 2010); "As a global society we are facing enormous challenges and opportunities as we move towards nine billion people on earth, and as we get closer to our "planetary boundaries" on key natural processes upon which we all depend." (Kering, 2014). Other companies referred to ecological limits to argue for the increasing importance of their products: "Aluminium shall... be a part of the solution to bringing about growth in a way that respects the limits of nature... The energy is not wasted when turned into aluminium, the energy is stored in the metal, enabling it to be recycled time and again" (NH, 2011). Many companies, especially in water supply and treatment, forestry and mining businesses, referred to their compliance with local ecological limits formalized in environmental legislation: "...The Corporation has bulk entitlements to water from the Thomson and Maribyrnong Rivers. During the year, the environmental flow requirements established by these bulk entitlements were met in both rivers...." (MWC, 2006). Common for these types of references to ecological limits is that they are not presented as a reason for changing "business as usual". This is not to imply that all companies within the A group are resisting sustainable transformations. Some companies may not perceive a need to signal changes to stakeholders if these consider existing products and production processes of such companies as compatible with (a transformation to) a sustainable society, i.e. a society not exceeding ecological limits. Yet, considering the need for sustainable transformations (Geels, 2011; Lorek and Spangenberg, 2014), it is striking that amongst companies demonstrating awareness of ecological limits only around $4 \%^{8}$ actively use ecological limits in stakeholder communication as reasons for changes in governance (group B) and business (group C) .

\subsubsection{Group B and C}

Based on the context analysis, we categorized 31 companies as group B and/or C, see Table 1. Certain aspects of each report made them qualify to the $B$ and/or $C$ group. These aspects are presented for each $C R$ report in $\mathrm{S} 4$ and examples are given below.

\section{[Insert Table 1 here]}

Of the 31 companies, 23 were categorized as group B companies, because they defined quantitative targets with deadlines for their resource consumptions or emissions based on ecological limits. Of these, six companies did not present a strategy for how to meet the target (group B1), while 17 presented such a strategy (group B2). An example of the former is Colgate-Palmolive Company. Although they presented an absolute GHG reduction target ( $50 \%$ in 2050 compared to 2002), it was unaccompanied by a strategy for how to meet it. An example of the latter is British Airways plc. They presented a strategy for how to meet their " 50 percent cut in net $\mathrm{CO}_{2}$ emissions by 2050 relative to 2005 ", which included a quantitative

\footnotetext{
${ }^{8}$ The fraction is in reality somewhat higher than $4 \%$ when considering the effect of classifying all companies not producing physical products ( $23 \%$ of all companies in the CorporateRegister database) as A companies in the context analysis (see Section 2.2).
} 
projection for how much each element in that strategy (New aircraft technology \& operational efficiency, Sustainable low-carbon fuels, Demand reduction and Purchase of emissions reductions) was expected to contribute to meeting the target. It was only possible to determine the system boundaries applied by 17 of the $23 \mathrm{~B}$ companies. Of these, eight, mainly Japanese producers of electronic consumer goods, applied a full life cycle boundary (either at the product level or aggregated production level). Other companies included one or more specific life cycle stages in their system boundary: Nine companies defined the boundary of their system around their own operations and their direct energy consumption (at the aggregated production level). Ford Motor Company and Nissan Motor Co applied a "Well-to-wheel" boundary (at the product level) ${ }^{9}$, whereas Skretting AS only covered their suppliers in their targeted shift from fish-based to agricultural-based fish feed. Also, a number of companies applied different system boundaries with different quantitative targets.

Almost all ecological limits based climate change targets were derived from estimated global GHG emission reductions, or reductions from Annex 1 countries, needed by 2050 in order to avoid exceeding the $2^{\circ} \mathrm{C}$ threshold. ${ }^{10}$ Many companies simply based their long term climate change target on a similar reduction percentage starting from a baseline year, thus implicitly adopting a grandfathering allocation approach, as further discussed in section 4.3. Some companies back-casted this long term target to determine milestones for near future years, e.g. 2020. Other companies used tools such as C-FACT (Autodesk, 2015) or The 3\% Solution (WWF, 2013) that are specifically designed to calculate annual reduction needs required to prevent exceeding the $2^{\circ} \mathrm{C}$ threshold. The development of corporate sustainability targets from other ecological limits than those related to climate change appear to be arbitrary and non-transparent (see Section 3.3.3 for the example of Ricoh Company Ltd). Of the 31 companies, we categorized 13 as group C companies, because they described a process of aligning their product portfolio to ecological limits. Of these, five companies presented ongoing adjustments (C1), while ten companies presented planned adjustments (C2). Two presented both (C1 and C2). One of these two, Galp Energia SGPS SA, for example, presented the $450 \mathrm{ppm}$ scenario of IEA as basis for its climate change strategy, which involved a change in business in the form of ongoing as well as planned increase in the provision and utilization of biofuels and other renewable energy sources.

In the $\mathrm{B}$ and $\mathrm{C}$ groups the number of Japanese companies is disproportionally large and other companies are mainly from the US or Europe (note that CR reports written in other languages than English were not covered by our study). With respect to coverage of environmental issues, the most common issue referred to is climate change with 27 of the 31 companies referring to related ecological limits such as " $2{ }^{\circ} \mathrm{C}$ " and "450 ppm." Ecological limits for fossil energy depletion, land use, resource use, water use, particulate matter and fisheries were only referred to by a few companies. Ricoh Company Ltd and Toshiba Corporation Semiconductor Company were the only companies that attempted to define reduction targets based on ecological limits for all environmental issues commonly covered in a Life Cycle Assessment (LCA), see section 3.3. With regards to sectors, "Automobile \& Parts" was the most widely represented $(5$ companies), while there were 4 companies from each of the two sectors "Electronic \& Electrical Equipment" and "Technology Hardware \& Equipment." Of the $31 \mathrm{~B}$ - and C-companies, 22 have only fit the criteria since 2010. Although a very low number of companies at present actively use ecological limits as

\footnotetext{
${ }^{9}$ A Well-to-wheel boundary encompasses fuel production (Well-to-tank) and vehicle use (Tank-to-wheel) (JEC, 2014)

${ }^{10}$ Many companies referred to the statement of the 4th IPCC assessment report that "a 50 to $85 \%$ reductions of 2000 levels by 2050 would be needed to stabilize at between 445 and $490 p p m$ (resulting in an estimated global temperature 2 to $2.4^{\circ} \mathrm{C}$ above the pre-industrial average)" (IPCC, 2007).
} 
reasons for changes in governance or business in stakeholder communication, an increasing trend can thus be observed.

\subsection{Longitudinal study of three group $B$ and $C$ companies}

Table 1 shows that only four companies fit the criteria for the $\mathrm{B}$ or $\mathrm{C}$ group for a minimum of 5 consecutive years (being one of the selection criteria for the longitudinal study, see Section 2.3). In order to obtain the largest possible diversity in sector, country of origin, system boundary applied and environmental problems covered, we selected from those the following three companies: Alstom SA, Nissan Motor Co Ltd and Ricoh Company Ltd (in the following referred to by the first word in the names only). The main commonality between these companies is that they all referred to and acted upon ecological limits related to climate change. Ricoh, in addition, addressed ecological limits related to all other environmental issues commonly quantified by an LCA. In the following we analyse how each company developed over time with regards to two aspects: 1) the presentation of planned changes based on ecological limits and 2) reporting of progress towards meeting these planned changes.

\subsubsection{Alstom}

Alstom has in its 2008-2012 reports made references to ecological limits related to climate change using terms such as "environmental constraint", " $450 \mathrm{ppm}$ " and " $2{ }^{\circ} \mathrm{C}$ ", and has acted upon these limits by describing ongoing ( $\mathrm{C} 1$ ) and planned (C2) adjustments related to its product portfolio. Alstom's argument for taking this approach rather than reducing internal emissions and resource use is that "Alstom's main contribution to environmental protection lies in the technologies it offers."(Alstom, 2008). Concretely, the planned product portfolio adjustments have varied over the years. In the beginning of the 2008-2012 period the focus was on carbon capture and storage (CCS). In later years CR reports emphasized planned products related to renewable energy technologies and thermal conversion technologies adaptable to the fluctuating conditions associated with a high proportion of renewable energy production in the grid. In 2013 and 2014 Alstom no longer made references to ecological limits, and in the 2014 report (the latest covered by this study) there is, perhaps incidentally, no reference to CCS, at all. With regards to on-going adjustments, Alstom continuously described some of its new products, such as " $\mathrm{CO}_{2}$ capture ready" power plant designs, as being compatible with an anticipated short-term transformation of the energy sector.

In terms of progress towards planned adjustments in product portfolio, the reports do not provide a direct indicator such as "share of revenue generated by product portfolio aligned to ecological limits." The company did, however, since 2012 report on the "cumulative annual, avoided $\mathrm{CO}_{2}$ " enabled by Alstom technologies in use worldwide when compared to "Business-as-Usual" scenarios. The cumulative avoidance due to Alstom's renewable technologies has increased significantly since 2002. Based on this indicator it is, however, difficult to evaluate whether the total annual avoidance caused by Alstom products is "high enough" in the light of overall reduction demands needed to satisfy the "450 ppm" or " $2{ }^{\circ} \mathrm{C}$ " limits. In 2010, Alstom noted a cumulative saving of $0.189 \mathrm{Gt} \mathrm{CO}_{2}$, which corresponds to $2 \%$ of the annual reduction requirement of the global power generation sector according to an IEA reduction scenario, designed to meet the $2^{\circ} \mathrm{C}$ target (both pieces of information were presented in the 2012 report). Whether these $2 \%$ were "high enough" may be judged by considering Alstom's global market share of the power generation sector, but such a comparison is not made in the CR reports. Although Alstom stops referring to ecological limits in 2013 and 2014, they continued reporting on avoided cumulative emissions. Rather than being driven by a need to communicate alignment to and performance against ecological limits, Alstom appears to be driven by regulation and high environmental concerns in general, as exemplified by the 2012 CEO statement: "Environmental concerns - and the regulations that go along with them - have been and will 
continue to be a growth driver for us. They spur demand for higher-tech products and more complex services." (Alstom, 2012).

\subsubsection{Nissan}

Amongst the case companies Nissan has fitted the criteria for the B or C group for the longest time, 8 years, and it is the only company that still matched these criteria in their most recent report at the time of writing (2014). Throughout the years, Nissan has consistently referred to " 2 degree" and they have used ecological limits to derive an initial governance target of a $70 \%$ reduction of "Well-to-wheel" $\mathrm{CO}_{2}$ emissions from new vehicles in 2050, compared with levels in 2000 (qualifying Nissan for the B group). In 2010, this target was increased to $90 \%$ (same target- and base year). The reason for this change is presumably that the original $70 \%$ target was based on not exceeding an atmospheric $\mathrm{CO}_{2}$ concentration of $550 \mathrm{ppm}$. The upwards revision of the target to $90 \%$ was likely in recognition of the updated IPCC estimate (IPCC, 2007), which stipulated that $\mathrm{CO}_{2}$ concentrations should in fact stay below $450 \mathrm{ppm}$ to avoid exceeding the 2 degree target. In 2012, Nissan announced a supplementary GHG reduction target for its corporate activities of $80 \%$ by 2050 compared to 2000 . This has a more direct link to the state of the climate than the "Well-to-wheel" target, because it is independent of the total travel distance of the vehicles sold. However, the Well-towheel target appears to be an increasing priority, given that it was mentioned in the CEO statements of the 2013 and 2014 reports, contrary to earlier years. Nissan also used the "2 degree" ecological limit as a stated reason for planned adjustments in product portfolio (qualifying it for the $\mathrm{C} 2$ group), e.g. "the spread of new types of electricity-powered vehicles, such as hybrid, full-cell and electric vehicles" and the company stressed that "The 70\% reduction target cannot be met even with these technologies, though, unless renewable energy is used to power the motors." (Nissan, 2007).

Throughout the 8-year period, Nissan has not reported the direct progress towards the "Well-to-wheel" target in terms of "\% reductions of 'Well-to-wheel' $\mathrm{CO}_{2}$ emission from new vehicles compared with levels in 2000", although such an indicator would seem practical given Nissan's knowledge of emissions figures for their different car models and their sales figures. Instead, Nissan has, from 2012 and onwards, reported on its progress towards a number of 2016 sub-targets that are linked to the 2050 "Well-to-wheel" target, albeit somewhat indirectly. It is, for instance, unclear how meeting the 2016 sub-target of " 20 million cumulative sales of CVT [continuously variable transmission]-equipped units" will contribute to meeting the 2050 target. With respect to its planned transition to engines directly or indirectly powered by renewable fuels, Nissan has in earlier reports focused on variants of electric vehicles (basic, plugin, hybrid) with improved battery technology, fuel-cell vehicles and vehicles running $100 \%$ on biofuels. In all cases, shortterm targets and progress towards these were presented. These planned product portfolio adjustments were in the most recent report (2014) maintained, except for the original proposal of vehicles running $100 \%$ on biofuels, which was no longer mentioned. In recent reports emphasis is given to more systemic issues, e.g. in the 2014 report Nissan presented the need for collaborating with other car manufactures, the public sector, etc. in establishing charging infrastructure. Furthermore, emphasis was put on the positive role Nissan can play by integrating its fleet of electrical vehicles in the grid (e.g. allowing charging of batteries when renewable electricity generation is peaking and feeding electricity back into the grid when demands exceed production).

\subsubsection{Ricoh}

Ricoh has been characterized as a B2 company in 2005-2009, because they in that period have had a consistent reduction target of $\mathbf{8 7 . 5 \%}$ for the "integrated environmental impact" of the full life cycle of their products at the aggregated production level for 2050 compared to 2000 , based on not exceeding the 
"tolerable impact" of an "ideal society." Integrated environmental impact is expressed in an Environmental Load Unit (ELU), which is a composite metric covering all impact categories of the EPS (environmental priority strategies) LCA impact assessment method (Bengt, 1999). References to "tolerable impact" began in the 2004 report and in the ensuing year the $87.5 \%$ target was first presented without a clear scientific rationale. In 2009, IPCC reports were stated as inspiration for the $87.5 \%$ target, even though the IPCC is not concerned with ecological limits unrelated to climate change. The $87.5 \%$ target was maintained in the 2014 report (the most recent at the time of writing), but this time restricted to GHG emissions and resource use - and the target was no longer motivated by an ecological limit or mentioned in the CEO statement (as was the case in the 2009 report).

Throughout the 2005-2009 period, Ricoh (like Nissan) established a number of sub-targets for 2007 (2005, 2006 and 2007 reports) and 2010 (2009 and 2010 reports), reportedly based on the $87.5 \%$ target, and reported progress towards meeting these sub-targets. Sub-targets mostly covered measures to reduce emissions from own operations, the development of in-use energy-saving products and improvement of product recycling and recycled content. As for Nissan, the quantitative relationship between these nearterm sub-targets and the overall target ( $87.5 \%$ reduction) is rather unclear. With respect to the reporting of progress towards meeting the $87.5 \&$ reduction target, it could be seen that, Ricoh, towards the end of every report, presented the full life cycle environmental impact at the aggregated production level for the two financial years prior to publication. Combining this information from reports published in 2005-2009, it can be observed that the impact actually increased from 2003 to $2008 .{ }^{11}$ This means that Ricoh in the period seem to have made negative progress towards meeting the $87.5 \%$ reduction target, and this may explain why the presentation of the target in the 2014 report was more cautious (i.e. no longer motivated by ecological limits or mentioned in CEO statement) and why 2011 was the last year, so far, Ricoh reported its total life cycle environmental impact.

\section{Discussion and conclusions}

We begin our discussion by firstly addressing the three focus points presented in the introduction. Secondly, we propose how future research can improve our understanding of the topic. Thirdly, we put the findings into perspective by providing recommendations to existing initiatives that seek to encourage companies to adopt ecological limits in their management and reporting practices. Before embarking on the discussion, it must be noted that while our study reveals the number of companies engaging with ecological limits in stakeholder communication and the manners of this engagement, they do not directly reveal why companies engage in this behavior, let alone relevant decision-making processes within companies. CR reports do not offer a "true" representation of companies, but can be seen as part of companies' response to existing or anticipated external pressure from e.g. suppliers, customers, policymakers, public opinion, competitors and social movements (Fernandez-Feijoo et al., 2014; Penna and Geels, 2012). Yet, in the discussions below we offer some explanations of the reasons behind the observed trends, while acknowledging that other explanations can co-exist.

\subsection{Trends in references}

The most striking result of our study is that very few companies use ecological limits as stated reasons for changing their products. This has only been the case for 31 of the database's pool of approximately 9000

\footnotetext{
${ }^{11}$ An increase or unchanged impact was observed between all neighboring years reported in each report. However, due to occasional changes in calculation method, the increase of impact in 2008 compared to 2003 cannot be quantified based on the reports.
} 
companies producing physical products. This seems to confirm the finding of CDP (2009), which, based on interviews of directors and managers within relevant departments of the world's 100 largest companies, concluded that "Company target setting is motivated by market forces, not scientific requirements." The recent attention given to ecological limits by NGOs and business organizations alike may lead to more companies considering scientific requirements in future target setting. Yet, many companies may perceive a long-term commitment to ecological limits based targets as a risk. This is because companies are used to regularly adjusting targets and strategies in response to unforeseen changes in e.g. raw material prices, demands of products or rapid technological developments. Such unforeseen changes are, scientifically speaking, not valid reasons for adjusting targets and strategies motivated by ecological limits, although the changes can make it harder (or easier) to meet the targets and strategies. Abandoning or easing reduction targets (originally) based on an ecological limit could therefore be interpreted by critical stakeholders as a clear sign of abandoning the ambition of becoming a sustainable company. Ricoh may be an example of a company trying to gradually abandon or adjusting its $87.5 \%$ reduction goal, which the company maintained in CR reports over several years, but later disconnected from its original ecological limits framing and removed from the prominent position in CEO statements.

Another noteworthy trend is that nearly half of the B- and C-companies belong to the Automobiles \& Parts sector (5 companies) and the technologically advanced Electronic \& Electrical Equipment or Technology Hardware \& Equipment sectors (8 companies). The relatively large number of car companies in these categories may, perhaps, be attributed to the tightening of regulation related to fuel economy in different countries and regions. For instance, the US Corporate Average Fuel Economy (CAFE) standards regulate the fleet fuel economy of automakers and tightens over time (Al-Alawi and Bradley, 2014). The CAFE standards were mentioned by Ford in their 2008 CR report in connection with a reduction goal, aligned with the 450 ppm climate threshold (Ford, 2008). For companies in the high-tech industry (e.g. Seiko Epson Corporation, Alstom SA and Cisco Systems Inc), regulation related to energy efficiency may also play a role. An additional reason for their relatively high representation in the $B$ and $C$ groups may be found in the rapid technological development within this industry which enables 1) large increases in eco-efficiency per unit of service (e.g. LCD monitors generally use much less electricity than cathode ray tube monitors) and 2) flexibility to pursue new business opportunities created by sustainable transformations, e.g. smart grid technologies for low-carbon energy systems. Geographical factors may also play a role. As such the predominance of Japanese companies amongst B- and C-companies may be explained by the country's historical focus on energy efficiency caused by its lack of domestic energy resources (EIA, 2014).

\subsection{Coverage of environmental issues}

Why are ecological limits related to climate change much more frequently mentioned in CR reports than ecological limits related to other environmental issues? Firstly, climate change has long been subject to much debate and the issue figures prominently on the political agenda worldwide. Consider, for example, the many policy documents in which the $2^{\circ} \mathrm{C}$ target, proposed by IPCC, has been adopted. Secondly, the universality of the $2^{\circ} \mathrm{C}$ target and relatively high scientific certainty of global GHG emission reduction requirements means that they can be translated into company-scale emission reduction requirements, irrespective of the geographical setting of companies. Thirdly, monitoring the manageable number of existing GHGs is relatively simple, and $\mathrm{CO}_{2}$ emissions can be estimated relatively precisely, based on fossil fuels consumption. By comparison, most other ecological limits are regional or local and may also vary naturally over time, which makes their translation into corporate level sustainability targets more challenging. Methods and tools for this translation are currently in their infancy (Bjørn and Hauschild, 2015; Bjørn et al., 2015; Ecofys, 2015) and years may pass before they reach a level of maturity that allow them 
to be as convenient to use as the ones for climate change (see e.g. Krabbe et al. (2015)). The fact that two $\mathrm{B}$ companies (Ricoh and Toshiba) simply applied the emission reduction percentage derived from the $2^{\circ} \mathrm{C}$ target to all LCA impact categories indicates that some companies intend to cover more than just climate change in their ecological limits based targets, but find it difficult to do so scientifically in practice. In addition we found many companies in the A group referring to ecological limits concepts related to water use such as Environmental Flow Requirement (Figure 1 and Table S2), but not a single company presenting a quantified reduction target for water use based on this ecological limits concept. This may be because, given the spatial and temporal variability in water availability, that it is highly impractical to communicate dynamic targets for each operation site, possibly including suppliers to stakeholders. Instead, we found that companies tend to commit qualitatively to taking regional or local water limitations into account by, for instance, conducting regular formal meetings with stakeholders of concerned watersheds. For instance, the mining company Teck wrote in their 2013 CR report that their approach to water management involves "collaborating with our COIs [communities of interest] to ensure the fair allocation of water." Note that such a commitment is relatively vague and difficult to hold companies accountable for, compared to e.g. a quantitative commitment to reduce GHG emissions in line with a climate target.

Another explanation for why there are so few references to other ecological limits than those related to climate change could be that critical stakeholders perceive some of the other environmental problems as 'solved' or sufficiently controlled by regulation, which gives companies little reason to aim for emissions below legal thresholds. Considering that $\mathrm{SO}_{x}$ and $\mathrm{NO}_{x}$ emissions from combustion processes are well regulated in most developed countries and the little public attention currently given to these emissions, this may explain why no company referred to ecological limits related to acidification and eutrophication.

\subsection{Allocation}

In a world of limited resources and assimilative capacity for pollutants, figuring out how to share these in a reasonable manner is of paramount importance. Yet few $B$ companies were explicit when it came to this issue of allocation. Instead, most of them implicitly adhered to the so-called grandfathering principle, where future emission rights are based on (a lenient granting of) historical emissions. In practice, this means applying the same emission reduction percentage to the corporate level as what is needed by all emitters combined to not exceed an ecological limit, compared to some base year. Although the grandfathering principle may appear intuitively appropriate it can be seen as unfair for two reasons: 1) Companies who historically have done little to reduce emissions will be entitled to relatively high emission levels at the expense of environmental frontrunners, 2) It does not preclude companies from outsourcing some of their activities and pollution instead of reducing emissions by technical means, if they only include their own operations in the system boundary. The grandfathering principle is also encouraged by "The 3\% Solution" initiative (WWF, 2013), in which US companies are asked to reduce absolute emissions of GHGs with on average $3.2 \%$ per year from a 2010 baseline year until $2020 .{ }^{12}$

Alternative allocation principles are proposed by other initiatives encouraging companies to define targets based on ecological limits: The GreenBiz initiative (2014) suggests introducing a universal GHG emission target relative to contribution to global GDP. This brings a different unfairness into the picture, because differences in industry characteristics are disregarded. For instance, companies within the service sector can easily appear sustainable, while dramatic GHG reductions for companies in energy and raw materialintensive sectors are required. A third principle was proposed by ClimateCounts (2013) which combined the

\footnotetext{
12 This reduction need was based on meeting an IPCC $2^{\circ} \mathrm{C}$-pathway in which developed countries by 2020 reduce GHG emissions by $25-40 \%$ below 1990 levels.
} 
grandfathering- and "contribution-to-GDP" principles through the use of baseline year emissions to define an initial company-specific GHG reduction pathway, which is then subject to regular adjustments based on changes in companies' revenues. A fourth principle was taken by CDP (2014) and Krabbe et al. (2015) which, as part of their "Science based targets" initiative, used the sector-specific reduction pathways of the International Energy Agency (IEA), designed to achieve the $2^{\circ} \mathrm{C}$ target, to construct a tool for companies to calculate GHG reduction needs, taking into account expected changes in production output. Other legitimate institutions whose reduction pathways could form the basis for allocation between companies are IPCC, nations and municipalities. No matter what allocation principle is applied, an additional concern is that for environmental issues with long-lasting effects, such as climate change, current and future reduction needs are functions of past emissions. As such, companies responsible for large historical emissions, e.g. many of those based in developed countries, can be seen as obliged to commit to the greatest reductions. This is reflected in the allocation adopted by The $3 \%$ Solution and ClimateCounts initiatives ${ }^{13}$ (ClimateCounts, 2013; WWF, 2013), but not in the one adopted by the GreenBiz and "Science based targets" initiatives (CDP, 2014; Krabbe et al. (2015); GreenBiz, 2014).

In the end, any allocation will inevitably lead to the perception of one or more parties being treated unfairly. This may explain why companies in our study largely refrained from dealing explicitly with the issue in their CR reports, which tend to reflect the dominant "win-win"-discourse (i.e. the belief that the economy of a company, the environment and all social actors can benefit from an action and that no tradeoffs exists) (Bamburg, 2015). Many companies, especially when reporting on resource limits related to wood, agricultural products and fish, instead framed the ecological limits issue qualitatively: For instance, furniture manufacturer Knoll Inc was aiming to only source FSC certified wood (Knoll, 2007), which involves harvesting wood "at or below a level which can be permanently sustained" (FSC, 2012). "Maintain or improve soils by preventing degradation" was part of The Coca-Cola Company's guidance for "sustainable sourcing" of agricultural products (Coca-Cola, 2013a, 2013b). Walmart Stores Inc required "its seafood suppliers to become third-party certified as sustainable" because an "estimated three quarters of the world's fisheries are at or beyond sustainable limits", meaning a ban on overfished species (Walmart, 2013). ${ }^{14}$ While this focus on local or specific sustainable practices is certainly important, it tends to divert attention from the fact that the Earth is a finite system. As illustrated by the ecological footprint method (Borucke et al., 2013), there is a limit to how many acres of forest and agricultural areas can be sourced sustainably. Similarly, a shift from sourcing overfished species to other less threatened species is likely to increase the pressure on these species that therefore may become at risk for being overfished as well. Thus, the allocation issue cannot be avoided when actors commit to collectively staying within ecological limits.

\subsection{Proposals for future research}

The growing pool of $C R$ reports is an increasingly rich source of information on how companies navigate the sustainability agenda outwardly. Our study found a surprisingly small number of companies that, judged by $\mathrm{CR}$ reports, acted upon the recognition of ecological limits. Companies may, however, present ambitious reduction targets or plan to change their product portfolios to accommodate the needs of a sustainable transformation of societies without referring to ecological limits: Within the Carbon Disclosure Project's list of organizations that have "committed to GHG emissions reduction targets that limit global warming to

\footnotetext{
${ }^{13}$ Both initiatives base company reduction needs on IPCC proposed reduction needs for developed countries, and not on global reduction needs.

${ }^{14}$ These three companies and others who framed ecological limits qualitatively were all categorized as group A companies in this study.
} 
below $2^{\circ} \mathrm{C}^{\prime \prime}(\mathrm{CDP}, 2015) 17$ companies, producing physical products, as of February 2015, do not figure in our list of $B$ companies (Table 1), while 5 companies do. The reason for this was found to be that these 17 companies do not refer to " $2^{\circ} \mathrm{C}$ " or any other climate change-related ecological limit in connection with presenting their commitment in their most recent CR reports. In benchmarking the ambitiousness of companies' environmental commitments against ecological limits (regardless of whether references to these are made in CR reports), the newly established Pivot Goals database of corporate sustainability targets may be helpful (J Gowdy Consulting, 2015). For such a benchmarking inspiration can be sought in the study of CDP (2009), which found that the targets of the world's 100 largest companies insufficiently contributed to avoiding dangerous climate change.

To improve the understanding of companies' adoption of the ecological limits concept, future research may draw upon the broader literature on drivers and barriers for implementation of environmental strategies in companies (Bey et al., 2013). Specifically, the role of public policies as a driver of company adoption of ecological limits deserves attention. Also, resource scarcity is a potential driver for companies' recognition and acting upon ecological limits: Although not necessarily related to ecological limits ${ }^{15}$, resource scarcity occurs partly because Earth is physically finite. Due to the economic impact of increasing or volatile prices, resource scarcity could act as an important driver for the broader adaptation of ecological limits and this mechanism deserves further attention.

Although the scope of this study has been restricted to companies producing physical products, there are other types of companies, particularly within the finance and retail industries, that can be associated with notable (direct or indirect) environmental effects and thereby contribution to exceeding various ecological limits. Future studies of the relationship between companies in the finance industry and ecological limits should consider the implications that divestment ${ }^{16}$ can have for the shift from fossil fuels to renewables. The relationship between retailers and ecological limits is also worth studying, since retailers can influence consumer demands by the types of products that they sell and how these products are presented in the stores. Also retailers, if large enough, can have a substantial influence on the behavior of their suppliers, as exemplified by Walmart's sustainability ranking of suppliers (Gunther, 2013).

Outside the scope of this study was also companies' use of the circular economy (EAF, 2014) and resilience ${ }^{17}$ (RAI, 2014) concepts in their CR reports. The relationship between companies' use of these increasingly popular concepts and (ecological limits framed) environmental sustainability in stakeholder communication make up relevant future research themes: It is important to identify conflicts in the simultaneous pursuit of environmental sustainability and resilience, because the former focuses on preventing ecological degradation by aligning business activities with ecological limits, while the latter is to some extent concerned with accommodating and adjusting to changes in environmental, social and economic conditions caused by ecological degradation. Also the question of whether companies attempt to use circular economy to legitimize not engaging with ecological limits in sustainability strategies and

\footnotetext{
15 The depletion of mineral deposits does not directly endanger any ecosystems, although emissions following this process might, which can be taken into account by emissions related ecological limits.

${ }^{16}$ Divestment is the reduction of assets in the fossil fuel sector based on an anticipated political will to prevent exceeding climate tipping points.

${ }^{17}$ The Resilience Action Initiative has provided the following definition: "Resilience is the capacity of business, economic and social structures to survive, adapt and grow in the face of change and uncertainty related to disturbances, whether they be caused by resource stresses, societal stresses and/or acute events" (RAI, 2014).
} 
stakeholder communication deserves attention, considering that even an ideal circular economy that is growing indefinitely is at odds with ecological limits (Bjørn and Hauschild, 2013; Townsend, 2014).

Methodologically, further studies of CR reports may utilize text analysis software to enable the identification of certain clusters of words associated with themes of interest, see e.g. Liew et al. (2014) and Sengers et al. (2010). This may be combined with a more qualitative approach to studying the extensive database of $\mathrm{CR}$ report. For example, text analysis software could be used to examine relationship between ecological limits terms and terms related to company-external drivers, such as regulation, raw material prices, media and civil society. The outcome could guide in-depth reading of selected reports, which could offer explanations as to why some companies refer to ecological limits and why references sometimes is used to frame or guide corporate targets and strategies. Such an extended analysis of stakeholder communication could be complemented by a study of internal corporate processes related to ecological limits via, for example, interviews with relevant managers and employees in a selected group of companies. Also, future research should pay attention to companies that do not communicate in English as these are likely to be situated in emerging economies that are predicted to substantially impact the global environment.

\subsection{Taking the limits seriously - some recommendations}

Recent initiatives encouraging companies to voluntarily adopt ecological limits can play a crucial role in increasing the currently very small number of companies that engage with ecological limits. Our study provides three prime recommendations for these recent initiatives.

Firstly, while climate change is recognized as a major threat to humanity, it is important that companies are urged to take a holistic approach in reporting their performance and targets in the context of ecological limits. If only climate change is considered, then there is a risk of burden shifting i.e. decreasing GHG emissions at the expense of increases of other environmental burdens, such as land use, water use or emissions of toxins (Laurent et al., 2012). While ecological limits for regional and local environmental issues can, for reasons given above, be challenging to incorporate in environmental strategies and reporting, this should not be an excuse for neglecting them. The WBCSD $(2014 ; 2009)$ and One Planet Thinking (Ecofys, 2015) initiatives are currently at the forefront when it comes to considering other issues than climate change, and are, hence, important sources of inspiration. See also Bjørn and Hauschild (2015) and Bjørn et al. (2015) for an attempt to operationalize ecological limits for use in LCA indicators.

Secondly, it is important that companies are encouraged to explicitly state the system boundary that they have chosen for their resource use and emission accounting and to argue why this boundary was chosen. The existing initiatives are currently split between encouraging a boundary encompassing a company' own operations and energy supply, while others encourage taking a full life cycle perspective. There is probably no single system boundary on which it is meaningful for all companies to base their reporting. Instead, sector-specific recommendations could be given. For instance, in light of the significant environmental impact of agriculture and the fact that farmers themselves usually do not report on sustainability issues, companies in the food producing and textile sectors should be encouraged to include supply chains in their system boundaries to align agricultural impacts (such as forest clearing, land erosion and emissions of pesticides and nutrients) with ecological limits of local ecosystems. The same goes for manufacturing companies that have outsourced large parts of their production to suppliers, who do not report on sustainability issues. 
Thirdly, we find it problematic that none of the recent initiatives appears to ask companies to reflect upon the role of their products in a societal transformation towards sustainability. Past eco-efficiency increases have been insufficient in decoupling increases in environmental impacts from economic growth (PricewaterhouseCoopers, 2014) and future efforts should therefore not assume that eco-efficiency increases alone can bring about the necessary industrial transformations (Huesemann, 2004). In our view, changes in how things are produced must be augmented by changes in what is being produced and, let's face it, a transformation of the economic system in which companies are embedded. Asking companies to question how their products help meeting needs (as opposed to wants) of current and future generations and to reconsider business models may seem like a futile endeavor, but the size of the challenge should not be an excuse for willful blindness.

\section{Acknowledgements}

We thank Michael Townsend (Earthshine Solutions) and three anonymous reviewers for providing valuable comments.

\section{Supporting information}

Supporting information is available online and contains S1) rationale for exclusion of certain search themes, S2) list of search terms, S3) number of relevant references per search term and S4) qualifying aspects for each of the $31 \mathrm{~B}$ and $\mathrm{C}$ companies. 


\section{References}

Al-Alawi, B.M., Bradley, T.H., 2014. Analysis of corporate average fuel economy regulation compliance scenarios inclusive of plug in hybrid vehicles. Appl. Energy 113, 1323-1337.

Alstom, 2008. Activity and Corporate Responsibility Report 2007/2008. Alstom SA.

Alstom, 2012. Activity and Sustainable Development Report 2011/12. Alstom SA.

Autodesk, 2015. Science-Based Climate Targets (C-FACT) [WWW Document]. URL http://sustainability.autodesk.com/available-solutions/c-fact/ (accessed 9.22.15).

Bamburg, J., 2015. A 2x2 to Change the World. Build. Sustain. Legacies New Front. Soc. Value Co-Creation 5.

Baue, B., 2013. Sustainability reporting: does G4 enhance sight but obscure vision? [WWW Document]. The Guardian. URL http://www.theguardian.com/sustainable-business/sustainability-reporting-g4-sightvision (accessed 9.22.15).

Baue, B., McElroy, M.W., 2013. Research needs and opportunities in Context-Based Sustainability. Financ. Report. 2, 47-70.

Bengt, S., 1999. A systematic approach to environmental priority strategies in product development (EPS). Version 2000 - General system characteristics. Chalmers University of Technology, Technical Environmental Planning.

Bey, N., Hauschild, M.Z., McAloone, T.C., 2013. Drivers and barriers for implementation of environmental strategies in manufacturing companies. CIRP Ann. - Manuf. Technol. 62, 43-46.

Bjørn, A., Hauschild, M.Z., 2013. Absolute versus Relative Environmental Sustainability. J. Ind. Ecol. 17, 321332.

Bjørn, A., Hauschild, M.Z., 2015. Introducing carrying capacity based normalization in LCA: framework and development of references at midpoint level. Int. J. Life cycle Assess. 20, 1005-1018.

Bjørn, A., Margni, M., Roy, P.O., Bulle, C., Hauschild, M.Z., 2015. A proposal to measure absolute environmental sustainability in Life Cycle Assessment. Ecol. Indic. DOI: 10.1016/j.ecolind.2015.11.046

Borucke, M., Moore, D., Cranston, G., Gracey, K., Iha, K., Larson, J., Lazarus, E., Morales, J.C., Wackernagel, M., Galli, A., 2013. Accounting for demand and supply of the biosphere's regenerative capacity: The National Footprint Accounts' underlying methodology and framework. Ecol. Indic. 24, 518-533.

Caldeira, K., Bala, G., Cao, L., 2013. The Science of Geoengineering. Annu. Rev. Earth Planet. Sci. 41, 231256. doi:10.1146/annurev-earth-042711-105548

CDP, 2009. The Carbon Chasm. Carbon Disclosure Project (CDP). 
Bjørn A, Bey N, Georg S, Røpke I, Hauschild M Z (2016); Is Earth recognized as a finite system in corporate responsibility reporting? Journal of Cleaner Production, Vol. xxx (2016), pp. 1-12, online 13 January 2016 http://dx.doi.org/10.1016/j.jclepro.2015.12.095

CDP, 2014. Methodology for setting corporate emission reduction targets in line with climate science: THE SECTORAL DECARBONIZATION APPROACH (SDA). Draft for Public Consultation. Carbon Disclosure Project, World Resources Institute and World Wildlife Fund.

CDP, 2015. Commit to business leadership on climate [WWW Document]. Carbon Disclosure Project. URL https://www.cdp.net/en-US/Pages/road-to-paris-2015.aspx (accessed 9.22.15).

ClimateCounts, 2013. Assessing Corporate Emissions Performance through the Lens of Climate Science. ClimateCounts \& Center for Sustainable Organizations.

Coca-Cola, 2013a. Coca-Cola 2012/2013 GRI Report. The Coca-Cola Company.

Coca-Cola, 2013b. Sustainable Agricultural Guiding Principles. The Coca-Cola Company.

Costanza, R., Daly, H.E., 1992. NATURAL CAPITAL AND SUSTAINABLE DEVELOPMENT. Conserv. Biol. 6, 3746.

CR, 2014a. CorporateRegister [WWW Document]. URL http://www.corporateregister.com (accessed 9.22.15).

CR, 2014b. CorporateRegister - About reports [WWW Document]. URL http://www.corporateregister.com/aboutreports.html (accessed 9.22.15).

EAF, 2014. Towards the Circular Economy vol.3: accelerating the scale-up across global supply chains. Ellen MacArthur Foundation.

Ecofys, 2015. One Planet Thinking(TM) [WWW Document]. URL https://www.oneplanetthinking.com/ (accessed 9.22.15).

EIA, 2014. US Energy Information Administration - analysis of Japan [WWW Document]. URL http://www.eia.gov/countries/cab.cfm?fips=ja\#note (accessed 2.28.15).

Fernandez-Feijoo, B., Romero, S., Ruiz, S., 2014. Commitment to Corporate social responsibility measured through global reporting initiative reporting: factors affecting the behavior of companies. J. Clean. Prod. 81, 244-254.

Ford, 2008. Blueprint for Sustainability 2007/8. Ford Motor Company.

FSC, 2012. FSC ${ }^{\circledR}$ International Standard FSC PRINCIPLES AND CRITERIA FOR FOREST STEWARDSHIP FSC-STD01-001 (V5-0) EN. Forest Stewardship Council.

Geels, F.W., 2011. The multi-level perspective on sustainability transitions: Responses to seven criticisms. Environ. Innov. Soc. Transitions 1, 24-40.

Giampietro, M., Saltelli, A., 2014. Footprints to nowhere. Ecol. Indic. 46, 610-621.

Goodland, R., 1995. The Concept of Environmental Sustainability. Annu. Rev. Ecol. Syst. 26, 1-24. 
Bjørn A, Bey N, Georg S, Røpke I, Hauschild M Z (2016);

Is Earth recognized as a finite system in corporate responsibility reporting? Journal of Cleaner Production, Vol. xxx (2016), pp. 1-12, online 13 January 2016 http://dx.doi.org/10.1016/j.jclepro.2015.12.095

GreenBiz, 2014. State of green business 2014. GreenBiz Group Inc.\& Trucost.

GRI, 2013. G4 Sustainability Reporting Guidelines - Implementation Manual. Global Reporting Initiative.

Gunther, M., 2013. Game on: Why Walmart is ranking suppliers on sustainability [WWW Document]. GreenBiz. URL http://www.greenbiz.com/blog/2013/04/15/game-why-walmart-ranking-supplierssustainability (accessed 9.22.15).

Hartley, R.J., Keen, E.M., Large, J.A., Tedd, L.A., 1990. Online Searching: Principles and Practice. Rr Bowker Llc, London.

Hettelingh, J.-P., Posch, M., Slootweg, J., Reinds, G.J., Spranger, T., Tarrason, L., 2007. Critical Loads and Dynamic Modelling to Assess European Areas at Risk of Acidification and Eutrophication. Water, Air, Soil Pollut. Focus 7, 379-384.

Hoff, H., Döll, P., Fader, M., Gerten, D., Hauser, S., Siebert, S., 2014. Water footprints of cities - indicators for sustainable consumption and production. Hydrol. Earth Syst. Sci. 18, 213-226.

Huesemann, M.H., 2004. The failure of eco-efficiency to guarantee sustainability: Future challenges for industrial ecology. Environ. Prog. 23, 264-270.

NH, 2011. Future proof: Infinite ideas in aluminum - Annual Report 2011. Norsk Hydro.

IPCC, 2007. Fourth Assessment Report: Climate Change 2007: The AR4 Synthesis Report. Geneva: IPCC, Geneva.

J Gowdy Consulting, 2015. Pivot Goals [WWW Document]. URL www.pivotgoals.com (accessed 9.22.15).

JEC, 2014. JEC Well-to-wheels analyses (WTW) [WWW Document]. Joint Research Centre of the European Commission. URL http://iet.jrc.ec.europa.eu/about-jec/jec-well-wheels-analyses-wtw (accessed 9.22.15).

Kering, 2014. Sustainability targets: Progress report. Kering.

Knoll, 2007. 2007 Environmental, Health \& Safety Annual Report. Knoll, Inc.

Krabbe, O., Linthorst, G., Blok, K., Crijns-Graus, W., van Vuuren, D.P., Höhne, N., Faria, P., Aden, N., Pineda, A.C., 2015. Aligning corporate greenhouse-gas emissions targets with climate goals. Nat. Clim. Chang. Nat. Clim. Chang. Nat Clim Chang. Nat. Clim. Chang.

Laurent, A., Olsen, S.I., Hauschild, M.Z., 2012. Limitations of carbon footprint as indicator of environmental sustainability. Environ. Sci. Technol. Environ. Sci. Technol 46, 4100-4108.

Liew, W. Te, Adhitya, A., Srinivasan, R., 2014. Sustainability trends in the process industries: A text miningbased analysis. Comput. Ind. 65, 393-400.

Lorek, S., Spangenberg, J.H., 2014. Sustainable consumption within a sustainable economy - beyond green growth and green economies. J. Clean. Prod. 63, 33-44. 
Bjørn A, Bey N, Georg S, Røpke I, Hauschild M Z (2016);

Is Earth recognized as a finite system in corporate responsibility reporting? Journal of Cleaner Production, Vol. xxx (2016), pp. 1-12, online 13 January 2016 http://dx.doi.org/10.1016/j.jclepro.2015.12.095

McElroy, M.W., van Engelen, J., 2012. Corporate Sustainability Management: The Art and Science of Managing Non-financial Performance, 1st ed. Earthscan, New York.

Milne, M.J., Gray, R., 2012. W(h)ither Ecology? The Triple Bottom Line, the Global Reporting Initiative, and Corporate Sustainability Reporting. J. Bus. Ethics 118, 13-29.

Moldan, B., Janoušková, S., Hák, T., 2012. How to understand and measure environmental sustainability: Indicators and targets. Ecol. Indic. 17, 4-13.

MWC, 2006. Melbourne Water Sustainability Report 2005/06. Melbourne Water Corporation.

Nissan, 2007. Sustainability Report 2007. Nissan Motor Co Ltd.

Pastor, a. V., Ludwig, F., Biemans, H., Hoff, H., Kabat, P., 2013. Accounting for environmental flow requirements in global water assessments. Hydrol. Earth Syst. Sci. Discuss. 10, 14987-15032.

Penna, C.C.R., Geels, F.W., 2012. Multi-dimensional struggles in the greening of industry: A dialectic issue lifecycle model and case study. Technol. Forecast. Soc. Change 79, 999-1020.

PricewaterhouseCoopers, 2014. Two degrees of separation: ambition and reality - Low Carbon Economy Index 2014. PricewaterhouseCoopers LLP.

RAI, 2014. Turbulence - A Corporate Perspective on Collaborating for Resilience. Resilience Action Initiative. Amsterdam.

Randers, J., 2012. Greenhouse gas emissions per unit of value added ("GEVA") - A corporate guide to voluntary climate action. Energy Policy 48, 46.

Ranganathan, J., Corbier, L., Bhatia, P., Schmitz, S., Gage, P., Oren, K., 2004. The Greenhouse Gas Protocol A Corporate Accounting and Reporting Standard. World Resources Institute; World Business Council for Sustainable Development.

Robinson, J., 2004. Squaring the circle? Some thoughts on the idea of sustainable development. Ecol. Econ. 48, 369-384.

Rockström, J., Steffen, W., Noone, K., 2009. Planetary boundaries: exploring the safe operating space for humanity. Ecol. Soc. 14, 32.

Schlosser, R.W., Wendt, O., Bhavnani, S., Nail-Chiwetalu, B., 2006. Use of information-seeking strategies for developing systematic reviews and engaging in evidence-based practice: the application of traditional and comprehensive Pearl Growing. A review. Int. J. Lang. Commun. Disord. 41, 567-82.

Sengers, F., Raven, R.P.J.M., Van Venrooij, a., 2010. From riches to rags: Biofuels, media discourses, and resistance to sustainable energy technologies. Energy Policy 38, 5013-5027.

Steffen, W., Richardson, K., Rockstrom, J., Cornell, S.E., Fetzer, I., Bennett, E.M., Biggs, R., Carpenter, S.R., de Vries, W., de Wit, C.A., Folke, C., Gerten, D., Heinke, J., Mace, G.M., Persson, L.M., Ramanathan, V., 
Bjørn A, Bey N, Georg S, Røpke I, Hauschild M Z (2016);

Is Earth recognized as a finite system in corporate responsibility reporting?

Journal of Cleaner Production, Vol. xxx (2016), pp. 1-12, online 13 January 2016 http://dx.doi.org/10.1016/j.jclepro.2015.12.095

Reyers, B., Sorlin, S., 2015. Planetary boundaries: Guiding human development on a changing planet. Sci. (washingt. D C) 347, 736.

SustainAbility, 1995. Who Needs It? Market Implications of Sustainable Lifestyles. SustainAbility Ltd.

Townsend, M., 2014. Growth - the real elephant in the room? [WWW Document]. edie.net. URL http://www.edie.net/library/Growth---the-real-elephant-in-the-room/6461 (accessed 9.22.15).

UG, 2010. Promising Futures: Sustainability Report for 2009-2010. University of Gloucestershire.

UNFCCC, 2009. Draft decision -/CP.15 Proposal by the President Copenhagen Accord. Copenhagen, Denmark.

Walmart, 2013. 2013 Global Responsibility Report. Wal-Mart Stores, Inc.

WBCSD, 2009. Vision 2050 - The new agenda for business. World Business Council for Sustainable Development, Genéve.

WBCSD, 2014. Action2020 [WWW Document]. World Business Council for Sustainable Development. URL http://action2020.org/ (accessed 9.22.15).

WCED, 1987. Report of the World Commission on environment and development: "our common future." United Nations, World Commission on Environment and Development, United Nations.

Whiteman, G., Walker, B., Perego, P., 2013. Planetary Boundaries: Ecological Foundations for Corporate Sustainability. J. Manag. Stud. 50, 307-336.

WRI, 2005. Millennium Ecosystem Assessment: Ecosystems and human well-being. Synthesis. Island Press, World Resources Institute, Washington, DC.

WWF, 2013. The 3\% solution - Driving Profits Through Carbon Reduction. World Wildlife Fund \& Carbon Disclosure Project. 
Bjørn A, Bey N, Georg S, Røpke I, Hauschild M Z (2016);

Is Earth recognized as a finite system in corporate responsibility reporting? Journal of Cleaner Production, Vol. xxx (2016), pp. 1-12, online 13 January 2016 http://dx.doi.org/10.1016/j.jclepro.2015.12.095

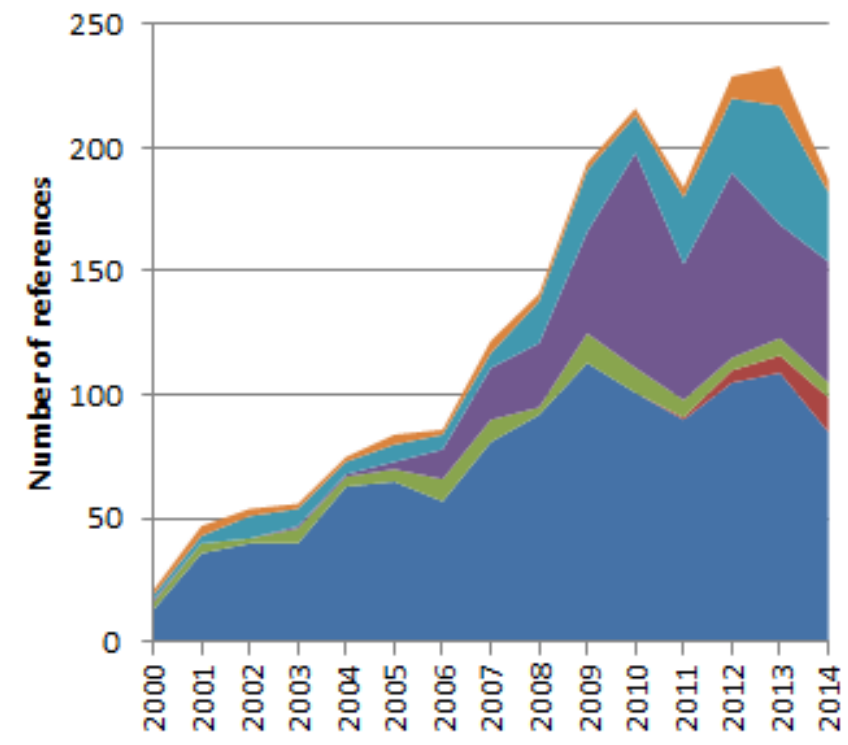

a)

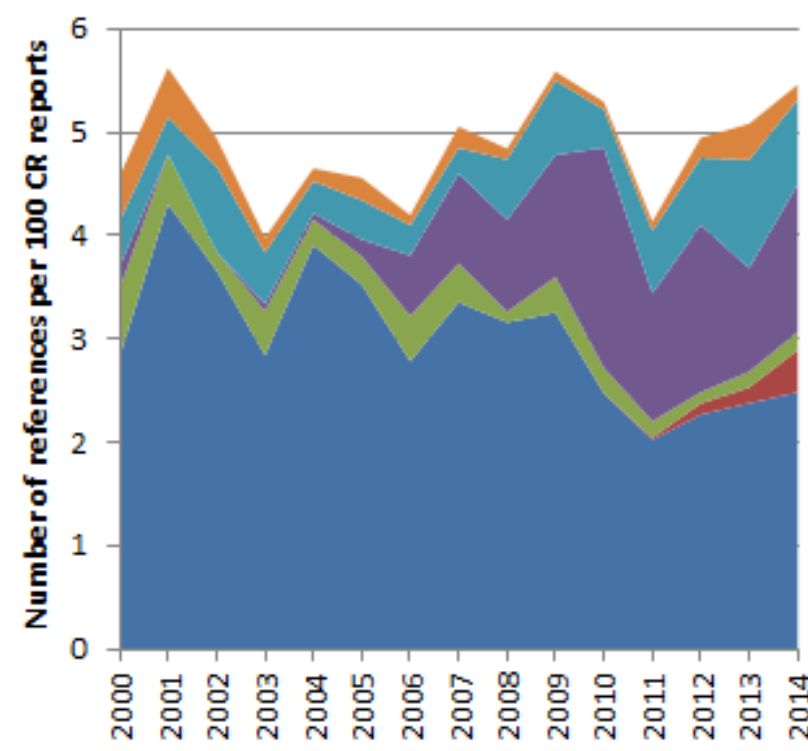

b)

Climate change $\quad$ Resource Water

Figure 1: The absolute number of references to ecological limits (a) and the number of references per $100 \mathrm{CR}$ reports (b) in the period 2000 - 24. November 2014 grouped into six themes. 
Table 1: Group B and C companies sorted by publication year. System boundaries for product level and aggregated production levels targets are in lower case letters and capital letters respectively. Semicolons separate different system boundaries for different targets (see S4).

\begin{tabular}{|c|c|c|c|c|c|c|}
\hline Name of company & Sector & Country & $\begin{array}{l}\text { Publication } \\
\text { year }\end{array}$ & Group & $\begin{array}{l}\text { System } \\
\text { boundary and } \\
\text { level }\end{array}$ & $\begin{array}{l}\text { Environmental } \\
\text { problem }\end{array}$ \\
\hline BMW AG & Automobiles \& Parts & Germany & 1999 & $\mathrm{C} 2$ & - & Climate change \\
\hline Ricoh Company Ltd & $\begin{array}{l}\text { Technology Hardware } \\
\text { \& Equipment }\end{array}$ & Japan & $\begin{array}{l}2005,2006, \\
2007,2008, \\
2009\end{array}$ & $\mathrm{~B} 2$ & FULL LIFE CYCLE & $\begin{array}{l}\text { All covered by } \\
\text { LCA indicators }\end{array}$ \\
\hline $\begin{array}{l}\text { Honda Motor } \\
\text { Company Ltd }\end{array}$ & Automobiles \& Parts & Japan & 2007 & $\mathrm{C} 2$ & - & Land use \\
\hline $\begin{array}{l}\text { Nissan Motor Co } \\
\text { Ltd }\end{array}$ & Automobiles \& Parts & Japan & $\begin{array}{l}2007,2008, \\
2009,2010, \\
2011,2012, \\
2013,2014\end{array}$ & $\mathrm{~B} 2, \mathrm{C} 2$ & $\begin{array}{l}\text { well-to-wheel; } \\
\text { OWN } \\
\text { OPERATIONS*** }\end{array}$ & Climate change \\
\hline $\begin{array}{l}\text { Spier Leisure } \\
\text { Holdings }\end{array}$ & Travel \& Leisure & South Africa & 2008 & B2 & $\begin{array}{l}\text { OWN } \\
\text { OPERATIONS*** }\end{array}$ & Climate change \\
\hline $\begin{array}{l}\text { Seiko Epson } \\
\text { Corporation }\end{array}$ & $\begin{array}{l}\text { Technology Hardware } \\
\text { \& Equipment }\end{array}$ & Japan & $\begin{array}{l}2008,2009, \\
2010,2011, \\
2012,2014\end{array}$ & B2 & full life cycle & Climate change \\
\hline Alstom SA & $\begin{array}{l}\text { Electronic \& Electrical } \\
\text { Equipment }\end{array}$ & France & $\begin{array}{l}2008,2009, \\
2010,2011^{*}, \\
2012\end{array}$ & $\mathrm{C} 1, \mathrm{C} 2$ & - & Climate change \\
\hline $\begin{array}{l}\text { Ford Motor } \\
\text { Company }\end{array}$ & Automobiles \& Parts & USA & $\begin{array}{l}2008,2009, \\
2011\end{array}$ & $\mathrm{~B} 2, \mathrm{C} 2$ & $\begin{array}{l}\text { well-to-wheel; } \\
\text { OWN } \\
\text { OPERATIONS*** }\end{array}$ & Climate change \\
\hline Hitachi Ltd & $\begin{array}{l}\text { Electronic \& Electrical } \\
\text { Equipment }\end{array}$ & Japan & 2008, 2010 & B2 & FULL LIFE CYCLE & Climate change \\
\hline Acciona SA & $\begin{array}{l}\text { Construction \& } \\
\text { Materials }\end{array}$ & Spain & 2010 & $\mathrm{~B} 2$ & Unclear & Climate change \\
\hline Danisco A/S & Food Producers & Denmark & 2010 & $\mathrm{C} 2$ & - & $\begin{array}{l}\text { Climate change, } \\
\text { water use, land } \\
\text { use, fossil } \\
\text { depletion, } \\
\text { toxicity } \\
\end{array}$ \\
\hline Electrolux $A B$ & Household Goods & Sweden & 2010 & $\mathrm{~B} 2$ & Unclear & Climate change \\
\hline Hitachi Koki Co Ltd & $\begin{array}{l}\text { Electronic \& Electrical } \\
\text { Equipment }\end{array}$ & Japan & $\begin{array}{l}2010 * *, 2011, \\
2012\end{array}$ & $\mathrm{~B} 2$ & FULL LIFE CYCLE & Climate change \\
\hline Samsung SDI Co Ltd & $\begin{array}{l}\text { Electronic \& Electrical } \\
\text { Equipment }\end{array}$ & \begin{tabular}{|l|} 
Republic of \\
Korea
\end{tabular} & 2010 & $\mathrm{C} 2$ & - & Climate change \\
\hline $\begin{array}{l}\text { Toshiba } \\
\text { Corporation } \\
\text { Semiconductor } \\
\text { Company }\end{array}$ & General Industrials & Japan & 2010 & B2 & full life cycle & $\begin{array}{l}\text { All covered by } \\
\text { LCA indicators }\end{array}$ \\
\hline Unilever plc / NV & Food Producers & UK & 2010 & B2 & $\begin{array}{l}\text { OWN } \\
\text { OPERATIONS***; } \\
\text { full life cycle }\end{array}$ & Climate change \\
\hline Iberdrola SA & Electricity & Spain & 2011 & B1 & Unclear & Climate change \\
\hline
\end{tabular}


Bjørn A, Bey N, Georg S, Røpke I, Hauschild M Z (2016);

Is Earth recognized as a finite system in corporate responsibility reporting? Journal of Cleaner Production, Vol. xxx (2016), pp. 1-12, online 13 January 2016 http://dx.doi.org/10.1016/j.jclepro.2015.12.095

\begin{tabular}{|c|c|c|c|c|c|c|}
\hline British Airways plc & Travel \& Leisure & UK & $\begin{array}{l}2011,2012, \\
2013\end{array}$ & B2 & Unclear & Climate change \\
\hline Alcatel-Lucent & $\begin{array}{l}\text { Technology Hardware } \\
\text { \& Equipment }\end{array}$ & France & 2012 & $\mathrm{~B} 2, \mathrm{C} 2$ & $\begin{array}{l}\text { OWN } \\
\text { OPERATIONS*** }\end{array}$ & Climate change \\
\hline $\begin{array}{l}\text { Bridgestone } \\
\text { Corporation }\end{array}$ & Automobiles \& Parts & Japan & 2012, 2013 & B2 & Unclear & Climate change \\
\hline $\begin{array}{l}\text { PTT Public } \\
\text { Company Limited }\end{array}$ & Oil \& Gas Producers & Thailand & 2012,2013 & B1 & $\begin{array}{l}\text { OWN } \\
\text { OPERATIONS*** }\end{array}$ & Climate change \\
\hline $\begin{array}{l}\text { Galp Energia SGPS } \\
\text { SA }\end{array}$ & Oil \& Gas Producers & Portugal & 2013 & $\mathrm{C} 1, \mathrm{C} 2$ & - & Climate change \\
\hline Skretting AS & Food Producers & Norway & 2013 & B2 & SUPPLIERS & Fishery \\
\hline Novelis Inc & Industrial Metals & USA & 2013, 2014 & $\mathrm{~B} 2$ & FULL LIFE CYCLE & Climate change \\
\hline $\begin{array}{l}\text { Zhong Xing } \\
\text { Telecommunication } \\
\text { Equipment } \\
\text { Company Limited } \\
\end{array}$ & $\begin{array}{l}\text { Fixed Line } \\
\text { Telecommunications }\end{array}$ & $\begin{array}{l}\text { People's } \\
\text { Republic of } \\
\text { China }\end{array}$ & 2013, 2014 & $\mathrm{C} 1$ & - & $\begin{array}{l}\text { Particulate } \\
\text { matter, toxicity }\end{array}$ \\
\hline Autodesk Inc & $\begin{array}{l}\text { Software \& Computer } \\
\text { Services }\end{array}$ & USA & 2014 & $\mathrm{~B} 2, \mathrm{C} 1$ & $\begin{array}{l}\text { OWN } \\
\text { OPERATIONS*** }\end{array}$ & Climate change \\
\hline BT Group plc & $\begin{array}{l}\text { Fixed Line } \\
\text { Telecommunications }\end{array}$ & UK & 2014 & $\mathrm{C} 2$ & 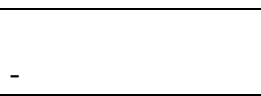 & Climate change \\
\hline Cisco Systems Inc & $\begin{array}{l}\text { Technology Hardware } \\
\text { \& Equipment }\end{array}$ & USA & 2014 & $\mathrm{~B} 1, \mathrm{C} 1$ & $\begin{array}{l}\text { OWN } \\
\text { OPERATIONS*** }\end{array}$ & Climate change \\
\hline $\begin{array}{l}\text { Colgate-Palmolive } \\
\text { Company }\end{array}$ & Personal Goods & USA & 2014 & $\mathrm{~B} 1$ & $\begin{array}{l}\text { OWN } \\
\text { OPERATIONS*** }\end{array}$ & Climate change \\
\hline Eneco Holding NV & $\begin{array}{l}\text { Gas, Water \& } \\
\text { Multiutilities }\end{array}$ & $\begin{array}{l}\text { The } \\
\text { Netherlands }\end{array}$ & 2014 & B1 & full life cycle & $\begin{array}{l}\text { Climate change, } \\
\text { fossil depletion, } \\
\text { particulate } \\
\text { matter }\end{array}$ \\
\hline Implats & Mining & South Africa & 2014 & B1 & Unclear & Climate change \\
\hline
\end{tabular}

*2010-2011 CR report was published in 2012. **2010 CR report published in 2011. *** Own operations include direct energy consumption (electricity, heat and steam) and thus corresponds to a scope 1-2 system boundary in the terminology of the Greenhouse Gas Protocol (Ranganathan et al., 2004) 